\title{
Effect of Herbal Medicine "Diabetocure" on Clinical and Biochemical Parameters of Diabetes
}

\author{
Ayush Garg ${ }^{1 *}$, Raj Kumar Vaya ${ }^{2}$ and Hitesh Chaturvedi ${ }^{1}$
}

\begin{abstract}
${ }^{1}$ Department of Pharmaceutics, Pacific College of Pharmacy, Udaipur-313024, Rajasthan, India
\end{abstract} ${ }^{2}$ Department of Pharmacology, Pacific College of Pharmacy, Udaipur-313024, Rajasthan, India

*Corresponding author: Ayush Garg, Department of Pharmaceutics, Pacific College of Pharmacy, Udaipur-313024, Rajasthan, India, E-mail: ayush20.garg@ gmail.com

Received: June 29, 2017; Revised: October 03, 2017; Published: October 13, 2017

Copyright: $(2017$ Garg A, et al. This is an open-access article distributed under the terms of the Creative Commons Attribution License, which permits unrestricted use, distribution, and reproduction in any medium, provided the original author and source are credited. The article has been previewed and authenticated by the Authors before sending the publication for print. The Journal, Editor and the Editorial Board are not entitled or liable to either justify or responsible for inaccurate and misleading data if any. It is the sole responsibility of the Author concerned.

Citation: Garg A, Vaya RK, Chaturvedi H. Effect of Herbal Medicine "Diabetocure" on Clinical and Biochemical Parameters of Diabetes. Int J Pharm Pharmacol 2017; 1: 120. doi: 10.31531/2581$\underline{3080.1000120}$

\begin{abstract}
Around 400 herbal treatments for diabetes mellitus are reported, but only a few of these have been approved of their therapeutic efficacy. Traditional treatments have mostly disappeared in occidental societies, but some are prescribed by practitioners of alternative medicine or taken by patients as supplements to conventional therapy. A hypoglycemic action from some treatments has been confirmed in animal models and non-insulin dependent diabetic patients, and various hypoglycemic compounds have been identified. The herbal substitutes for insulin and related anti-diabetic drugs seems challenging, but herbal treatments can provide valuable clues for the development of new oral hypoglycemic agents and simple dietary adjuncts.
\end{abstract}

Keywords: Diabetes, Insulin, Metabolic, Hypoglycaemia, Alloxan

\section{Introduction}

Diabetes is a metabolic disorder characterized by chronically elevated blood glucose above the normal range. It may occur either due to insufficiency of pancreas to produce insulin or when the body cannot effectively utilize the secreted insulin. Insulin is a hormone that regulates blood sugar. Hyperglycemia, or raised blood sugar, is a common effect of uncontrolled diabetes and over time leads to serious damage to many of the body's systems, especially the nerves and blood vessels.

WHO reporting for diabetes mellitus is as follows:

- 347 million people worldwide have diabetes $[1,2]$.

- In 2004, an estimated 3.4 million people died from consequences of high fasting blood sugar [3]. 
- The middle and low-income countries have reported more than $80 \%$ of diabetes deaths [4].

- According to WHO, diabetes will be the $7^{\text {th }}$ leading factor of death by 2030 [5].

- Healthy diet, regular physical activity, maintaining a normal body weight and avoiding tobacco use can prevent or delay the onset of type II diabetes.

\section{Types of Diabetes}

Greek and Roman physicians used the term "Diabetes" to refer to conditions that result in large urine volume and are classified it into two types [6].

- Diabetes mellitus in which the urine tasted sweet.

- Diabetes inspidus in which the urine tasted tasteless.

\section{Regulation of Blood Glucose and Diabetes}

Diabetes mellitus is the most important disease involving the endocrine pancreas. The secretion of the pancreas is digestive in function and the internal secretions plays a major role in the regulation of metabolism. The hormones which regulates the level of blood glucose are mainly two-

- Glucagon from the $\alpha$-cells,

- Insulin from the $\beta$ cells of the islets of langerhans.

Diabetes mellitus is characterized by:

I. Hyperglycemia with a deranged secretion of insulin and possibly glucagons.

II. Altered metabolism of lipids, carbohydrates and proteins.

III. An increased risk of complications from vascular disease.

Diabetes is characterized by symptoms like polyuria (increase in urine output), increase in thirst (polydipsia), loss of weight and polyphagia (increased appetite) as major symptoms of insulin deficiency [7-9] Beside these, hyperglycemia (increase in blood glucose concentration), glucosuria (presence of glucose in urine), ketonuria and ketonemia (increased concentration of ketone bodies in the blood and urine) and muscular weakness have also been reported. Long-term complications involve cardiovascular diseases (stroke and myocardial infraction), renal disease (diabetic nephropathy), loss of nerve function (diabetic neuropathy) and proliferative scarring of the retina (diabetic retinopathy) $[6,10]$.

The symptoms of Diabetes mellitus results from real or apparent insufficient insulin secretion or possibly from overabundance of some insulin-inhibiting factor such as hypersecretion of anterior pituitary gland or adrenal gland. The result is as elevated blood glucose level; as the blood glucose level exceeds its renal threshold, glucose appears in the urine. With the increase in the blood glucose concentration, the blood volume increases, thereby enhancing the urine output. This triggers the compensatory adjustment, which leads to increase in thirst. A need for alternate source of energy due to the inability of glucose to enter some tissues increases the concentration of ketone bodies synthesized by liver in the blood and urine.

Insulin promotes lipogenesis and inhibits their breakdown. The failure of normal utilization of glucose in the tissue is accompanied by increased production of free fatty acids, which are formed more rapidly than they are consumed. Hypoglycemia stimulates ketogenesis. Fragments such as acetoacetic acid, acetone and $\alpha$ - hydroxy butyric acid are formed in excessive amount and accumulate in the blood and tissue resulting into diabetic acidosis, ketosis and finally coma and death [8].

\section{Types of Diabetes Mellitus}

There are two types of Diabetes mellitus [11].

I. Type I Diabetes (insulin-dependent Diabetes or IDDM, also called as juvenile onset Diabetes mellitus), and

II. Type II Diabetes (non-insulin dependent Diabetes or NIDDM, also called maturity onset Diabetes).

Materials and Methods 


\section{Procedure for different parameters}

\section{Determination of alcohol soluble extractive}

$5 \mathrm{~g}$ of coarsely powdered, air dried drug, was macerated with $100 \mathrm{ml}$ of ethanol of the specified strength in a closed flask for $24 \mathrm{~h}$. It was frequently shaken for six hours and allowed to stand for 18 hours. It was then filtered rapidly and loss of ethanol during the process was cautioned. Further, it was evaporated to dryness in a tarred, flat bottom shallow dish, dried at $105 \pm 1{ }^{\circ} \mathrm{C}$ and weighed. The percentage of alcohol soluble extractive was calculated with reference to the air-dried drug [12-14].

\section{Determination of water soluble extractive}

$5 \mathrm{~g}$ of air dried drug, coarsely powdered, was macerated with $100 \mathrm{ml}$ of water in a closed flask for $24 \mathrm{~h}$, shaking frequently for $6 \mathrm{~h}$ and allowed to stand for $18 \mathrm{~h}$. filtered rapidly taking precautions against loss of chloroform water. Evaporated to dryness in a tarred flat bottom shallow dish, dried at $105 \pm 1^{\circ} \mathrm{C}$ and weighed. Calculated the percentage of water soluble extractive with reference to the air-dried drug $[14,15]$.

\section{Determination of Benzene soluble extractive:}

$5 \mathrm{~g}$ of air dried drug, coarsely powdered, was macerated with $100 \mathrm{ml}$ of benzene of specified strength in a closed flask for $24 \mathrm{~h}$. It was shaken frequently for six hours and allowed to stand for $18 \mathrm{~h}$. It was then filtered rapidly and loss of chloroform water was avoided during the process. The macerated product was evaporated to dryness in a tarred flat bottom shallow dish, dried at $105 \pm 1{ }^{\circ} \mathrm{C}$ and then weighed. The percentage of water soluble extractive was calculated with reference to the air-dried drug [14-16].

\section{Determination of Petroleum ether extractive}

$5 \mathrm{~g}$ of, coarsely powdered, air dried drug, was macerated with $100 \mathrm{ml}$ of petroleum ether of specified strength in a closed flask for $24 \mathrm{~h}$, frequently shaken for $6 \mathrm{~h}$ and allowed to stand for 18 hours. It was rapidly filtered and loss of chloroform water was prevented. It was then evaporated to dryness in a tarred flat bottom shallow dish, dried at $105 \pm 1{ }^{\circ} \mathrm{C}$ and finally weighed. The percentage of water soluble extractive was calculated with reference to the air-dried drug [17].

\section{Determination of Hydro-alcohol extractive}

Macerated $5 \mathrm{~g}$ of air dried drug coarsely powdered with mixture of $70 \mathrm{ml}$ of ethanol and $30 \mathrm{ml}$ water in a closed flask for $24 \mathrm{~h}$, shaking frequently during $6 \mathrm{~h}$ and allowed to stand for $18 \mathrm{~h}$. filtered rapidly taking precautions against loss of ethanol. Evaporated to dryness in a tarred flat bottom shallow dish, dried at $105 \pm$ $1^{\circ} \mathrm{C}$ and weighed. Calculated the percentage of alcohol soluble extractive with reference to the air-dried drug $[16,17]$

\section{Loss on drying}

About 2-3 g of powder is accurately weighed in a china dish and kept in hot air oven maintained at $110 \pm 1{ }^{\circ} \mathrm{C}$ for four hours. After cooling in a dessicator, the loss in weight was recorded. This procedure was repeated till constant weight was obtained [18].

Loss on drying $(\%)=$ Loss in weight $\mathrm{X}$ 100/Weight of the drug in gm

\section{Determination of ash value}

Take 2-3 g, powdered crude drug in a tarred silica dish, it was ignited and weighed. The powder drug was scattered on the bottom of the dish, incinerated by gradually increasing the heat, not exceeding dull red heat until free from carbon, cool and then finally weighed $[18,19]$.

Total ash value of sample $\%=\underline{z-x} X 100 / y$

Where, $\mathrm{z}=$ weight of the dish + Ash (after complete incineration)

$$
\begin{aligned}
& x=\text { weight of empty dish } \\
& y=\text { weight of drug taken }
\end{aligned}
$$

\section{Determination of acid insoluble ash}

The ash was boiled with $25 \mathrm{ml}$ of dilute $\mathrm{HCl}$ for 5-10 min. The insoluble matter was collected in a Gooch crucible, washed with hot water, ignited and weighed. The percentage of 
acid insoluble ash was calculated with reference to air dried drug $[19,20]$

Acid insoluble ash value of the sample \%

$=\mathrm{a} X 100 / \mathrm{y}$

Where, $\mathrm{a}=$ weight of the residue

$\mathrm{y}=$ weight of air dried drug

\section{Determination of water soluble ash}

Boil the ash for 5-10 min with $25 \mathrm{ml}$ of water, collected the insoluble matter in a Gooch crucible, washed with hot water and ignited to constant weight at a low temperature. The weight of insoluble matter was subtracted from the weight of ash. The difference in weight shows the water-soluble ash. The percentage of water soluble ash was calculated with reference to the air-dried drug [21].

Water soluble ash-Weight of insoluble matter Percentage of water soluble ash $=\mathrm{a} X 100 / \mathrm{b}$

Where, $\mathrm{a}=$ water soluble ash

$\mathrm{b}=$ air dried drug

\section{Anti-diabetic activity study}

Screening of anti-diabetic activity of selected medicinal plant extracts were done in rats by conducting oral glucose tolerance test (OGTT) study and evaluating their effects in single dose (acute) and multi dose (sub-acute) treatment of plant extracts, flavonoids and standard drug study on blood glucose level, serum lipid profile and histology of pancreas in Alloxan and streptozotocin induced diabetic rats [22].

\section{Oral Glucose Tolerance Test (OGTT) [22,23]}

Fasting blood glucose level of each rat was determined at zero time after overnight fasting with free access to water. Rats were divided into ten groups containing six rats each.

\section{Group I}

Rats were given only vehicle (only water)

\section{Group II}

Rats were given glucose in single dose $(2 \mathrm{~g} / \mathrm{kg}$, bw, p.o.)

Garg A, et al. Int J Pharm Pharmacol

\section{Group III}

Animal were given glucose $(2 \mathrm{~g} / \mathrm{kg}$, bw, p.o.) single dose + drug Gilbenclamide $(5 \mathrm{mg} / \mathrm{kg}$ bw, p.o.)

\section{Group IV}

Rats were given glucose $(2 \mathrm{~g} / \mathrm{kg}$, bw, p.o.) + drug powder $(200 \mathrm{mg} / \mathrm{kg} /$ day, bw, p.o.)

\section{Group V}

Rats were given glucose $(2 \mathrm{~g} / \mathrm{kg}$, bw, p.o.) +, drug powder ( $400 \mathrm{mg} / \mathrm{kg} / \mathrm{day}$, bw, p.o.). These animals received their doses by oral route using an orogastric tube. Glucose $(2 \mathrm{~g} / \mathrm{kg})$ was orally administered 30 minutes after the administration of the plant powder, standard drug (Gilbenclamide) and vehicle (water). Glucose level was estimated using glucoseoxidase-perxosidase reactive strips and glucometer [24].

\section{Alloxan induced diabetes in Rats (Single dose study) [25-27].}

The animals were selected and weighed than marked for individual identification. The rats were injected with Alloxan monohydrate dissolve in sterile normal saline $(0.9 \% \mathrm{NaCl})$ at a dose of $60 \mathrm{mg} / \mathrm{kg}$ body weight, intraperitoneally to induce diabetes in overnight fasted male wistar albino rats weighing 175$200 \mathrm{~g}$. The animals were given feed ad libitum after one hour of alloxan administration. To overcome the early hypoglycaemic phase, a 5\% dextrose solution was fed for a day. After $72 \mathrm{~h}$, the animals with blood glucose levels more than $250 \mathrm{mg} / \mathrm{dl}$ were considered diabetic and were included in the study. Rats were divided into ten groups containing six rats each.

\section{Group I}

Rats were given only vehicle (only water)

\section{Group II}

Rats were given alloxan in single dose $(60 \mathrm{mg}$ $/ \mathrm{kg}$, bw, i.p.)

\section{Group III}

Animal were given alloxan $(60 \mathrm{mg} / \mathrm{kg}$, bw, i.p.) single dose + drug Gilbenclamide (5 $\mathrm{mg} / \mathrm{kg}$ bw, p.o.)

\section{Group IV}


Rats were given alloxan $(60 \mathrm{mg} / \mathrm{kg}$, bw, i.p. $)+$ drug powder $(200 \mathrm{mg} / \mathrm{kg} /$ day, bw, p.o.)

\section{Group V}

Rats were given alloxan $(60 \mathrm{mg} / \mathrm{kg}$, bw, i.p. $)+$ drug powder $(400 \mathrm{mg} / \mathrm{kg} / \mathrm{day}, \mathrm{bw}$, p.o.)

For single dose study blood samples were collected from the tail vein prior to and at 2, 4, 6 and 8 hours intervals and for multi dose study blood sample were collected on 0, 5, 10 and 15 days after the administration of the plant powder, standard drug (Gilbenclamide) and vehicle (water). Glucose level was estimated using glucose-oxidase-perxosidase reactive strips and glucometer.

Serum lipid profiles on day 15 were measured by an autoanalyzer, pancreas histopathological examination was performed after sacrificing the animal under anesthesia on $15^{\text {th }}$ day and body weight measurement were carried out on days $0,5,10$ and 15 of study. Glucose level was estimated

\section{Streptozotocin induced diabetes in Rats (Single dose study) [28,29]}

The animals were selected and weighed than marked for individual identification. The rats were injected with streptozotocin dissolve in $0.1 \mathrm{M}$ citrate buffer at a dose of $70 \mathrm{mg} / \mathrm{kg}$ body weight, interperitonially to induce diabetes in overnight fasted male wistar albino rats weighing 175-200 g. The animals were given feed ad libitum after one hour of streptozotocin administration. To overcome the early hypoglycaemic phase, a 5\% dextrose solution was fed for one day. After 72 hours, animals with blood glucose levels higher than 250 $\mathrm{mg} / \mathrm{dl}$ were considered diabetic and were included in the study. Rats were divided into ten groups containing six rats each.

\section{Group I}

Rats were given only vehicle (only water)

\section{Group II}

Rats were given streptozotocin in single dose (70 mg /kg, bw, i.p.)

\section{Group III}

Animal were given streptozotocin $(70 \mathrm{mg} / \mathrm{kg}$, bw, i.p.) single dose + drug Gilbenclamide (5 $\mathrm{mg} / \mathrm{kg}$ bw, p.o.)

\section{Group IV}

Rats were given streptozotocin $(70 \mathrm{mg} / \mathrm{kg}$, bw, i.p. $)+\operatorname{drug}$ powder $(200 \mathrm{mg} / \mathrm{kg} / \mathrm{day}$, bw, p.o. $)$

\section{Group V}

Rats were given streptozotocin $(70 \mathrm{mg} / \mathrm{kg}$, bw, i.p.) + drug powder (400 mg/ kg/ day, bw, p.o.) For single dose study blood samples were collected from the tail vein prior to and at 2, 4, 6 and $8 \mathrm{~h}$ intervals and for multi dose study blood sample were collected on $0,5,10$ and 15 days after the administration of the plant powder, standard drug (Gilbenclamide) and vehicle (water). Glucose level was estimated using glucose-oxidase-perxosidase reactive strips and glucometer.

Body weight measurement was carried out on days $0,5,10$ and 15 of study [30].

\section{Result and Discussion}

\section{Physico-chemical characterization of drug powder}

All plants were powdered and mixed their different parts to form powder were evaluated for various organoleptic and morphological characteristics like nature, colour, odour, and taste. The observed characteristics were correlated with the literature to validate the authenticity of the crude drug under investigation. Moisture and volatile content were found to be less than $10 \% \mathrm{w} / \mathrm{w}$ indicating that individual plant material has been properly dried.

Extractive values were determined by maceration process using non-polar solvent petroleum ether $\left(40-60^{\circ} \mathrm{C}\right)$, benzene and polar solvent ethanol and water. The extractive values of plant powder have been found to be 13.80 to $19.17 \%$ w/w with polar solventsethanol and water and $12.30 \% \mathrm{w} / \mathrm{w}$ to $11.26 \%$ w/w with non-polar solvent - petroleum ether $\left(40-60^{\circ} \mathrm{C}\right)$ and benzene. This indicates that both polar and non-polar constituents were present in plants powder. Results are indicated in Table 1. 
Table 1: Physico-chemical characterization of drug powder

\begin{tabular}{|c|c|c|}
\hline S.No. & Parameters & Observation \\
\hline \multirow{5}{*}{$\mathbf{I}$} & \multicolumn{2}{|c|}{ Physical Tests } \\
\hline & Nature & Coarse Powder \\
\hline & Color & Brown (Light Brick red) \\
\hline & Odour & Characteristic \\
\hline & Taste & No taste or slight Bitter \\
\hline \multirow{6}{*}{ II } & \multicolumn{2}{|c|}{ Extractive values } \\
\hline & Aqueous & $13.82 \%$ \\
\hline & Alcohol & $15.44 \%$ \\
\hline & Benzene & $12.30 \%$ \\
\hline & Petroleum Ether & $11.26 \%$ \\
\hline & Hydro -Alcoholic (70:30) & $19.17 \%$ \\
\hline III & Loss on drying & $11 \%$ \\
\hline \multirow[t]{4}{*}{ IV } & \multicolumn{2}{|c|}{ Ash values } \\
\hline & Total ash & $12 \%$ \\
\hline & Acid insoluble ash & $3 \%$ \\
\hline & Water soluble ash & $1 \%$ \\
\hline
\end{tabular}

Table 2: Effect of plant powder and standard drug on the blood glucose levels in glucose loaded rats (OGTT)

\begin{tabular}{|c|c|c|c|c|c|c|}
\hline Group & 0 min & 30 min & $60 \mathrm{~min}$ & $120 \mathrm{~min}$ & $240 \mathrm{~min}$ & $\begin{array}{l}\% \text { reduction of } \\
\text { blood glucose level } \\
\text { after } 4 \mathrm{~h}\end{array}$ \\
\hline I & $\begin{array}{ll}92.95 & \pm \\
0.789 & \end{array}$ & $92.66 \pm 0.794$ & $\begin{array}{ll}93.11 & \pm \\
0.599 & \end{array}$ & $91.83 \pm 0.772$ & $\begin{array}{l}91.08 \pm \\
0.802\end{array}$ & - \\
\hline II & $\begin{array}{l}92.95 \\
1.224\end{array}$ & $170.93 \pm 1.397$ & $\begin{array}{l}174.21 \quad \pm \\
2.335\end{array}$ & $170.13 \pm 1.388$ & $\begin{array}{l}141.43 \pm \\
3.549\end{array}$ & - \\
\hline III & $\begin{array}{ll}93.65 & \pm \\
0.999 & \end{array}$ & $166.0 \pm 3.038$ & $\begin{array}{l}158.55 \quad \pm \\
2.519\end{array}$ & $146.8 \pm 2.682$ & $\begin{array}{l}110.46 \pm \\
3.268\end{array}$ & $15.21 \%$ \\
\hline IV & $\begin{array}{l}92.26 \quad \pm \\
1.175\end{array}$ & $162.73 \pm 2.570$ & $\begin{array}{l}161.31 \quad \pm \\
2.688\end{array}$ & $152.56 \pm 2.419$ & $\begin{array}{l}112.35 \pm \\
2.839\end{array}$ & $17.88 \%$ \\
\hline $\mathbf{V}$ & $92.11 \pm$ & $154.75 \pm 2.537$ & 158.6 & $148.08 \pm 2.153$ & $108.11 \pm$ & $14.66 \%$ \\
\hline
\end{tabular}




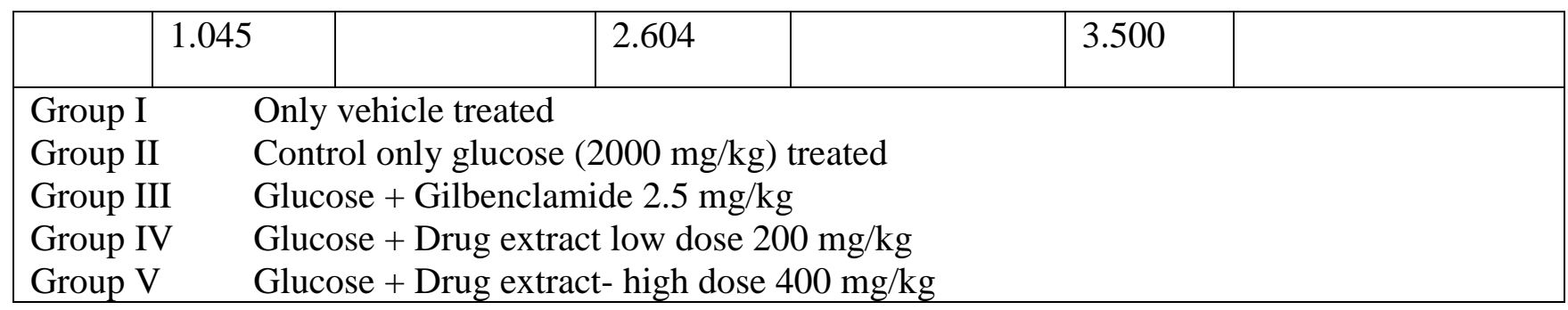

\section{Anti-diabetic Activity}

Effect of plant powder and standard drug on the blood glucose levels in glucose loaded rats (OGTT)

Glucose at dose of $2 \mathrm{~g} / \mathrm{kg}$ was orally administered, after the administration of different treatment. Blood glucose level was estimated at zero, 30, 60, 120 and 240 min after treatment. Percentage reduction in Blood glucose level in different treated groups after $240 \mathrm{~min}$ was measured and found to be 34.27 , 15.21, 17.88 and $14.66 \%$ for glibenclamide, Drug extract at low dose $200 \mathrm{mg} / \mathrm{kg}$ and Drug extract at dose $400 \mathrm{mg} / \mathrm{kg}$ treated group respectively.

Hypoglycemic effect in glucose treated model. Results of OGTT are given in Table 2 and Figure 1.

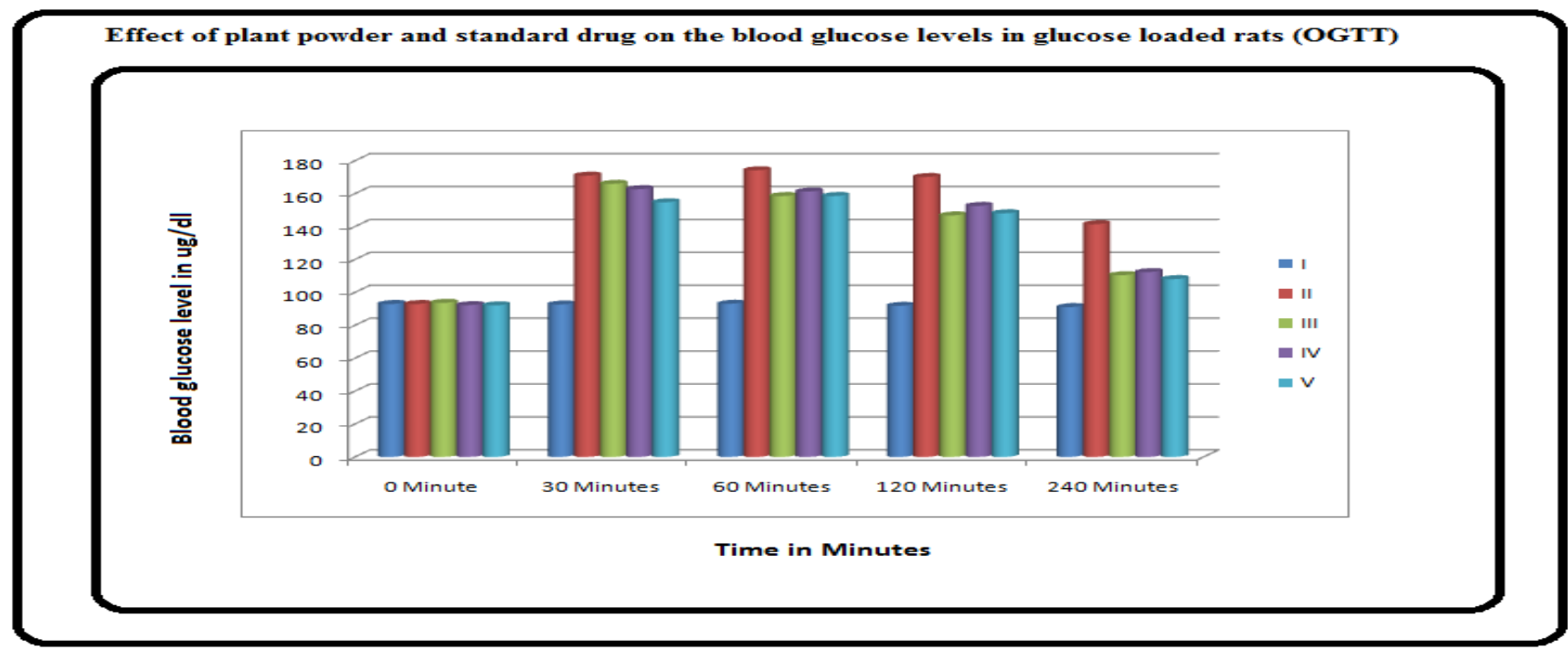

Figure 1: Effect of plant powder and standard drug on the blood glucose levels in glucose loaded rats (OGTT)

Table 3: Effect of plant powder and standard drug on the blood glucose levels in alloxan induced diabetic rats (Single dose study)

\begin{tabular}{|l|c|c|c|c|c|c|}
\hline Group & $\mathbf{0 ~ h}$ & $\mathbf{2 ~ h}$ & $\mathbf{4 h}$ & $\mathbf{6 ~ h}$ & $\mathbf{8 ~ h}$ & $\begin{array}{c}\text { \% reduction of } \\
\text { blood glucose } \\
\text { level after 8 h }\end{array}$ \\
\hline I & $\begin{array}{c}92.51 \pm \\
1.17\end{array}$ & $\begin{array}{c}92.7 \pm \\
1.10\end{array}$ & $92.7 \pm 1.00$ & $93.3 \pm 0.97$ & $93.1 \pm 0.95$ & - \\
\hline II & $274.8 \pm$ & $289 \pm 2.40$ & $296.8 \pm 1.76$ & $283.6 \pm$ & $275.8 \pm$ & 1.15 \\
& 2.22 & & & 1.56 & & \\
\hline III & $279.9 \pm$ & $243.9 \pm$ & $234.7 \pm 1.95$ & $220.3 \pm$ & $212.0 \pm$ & $24.25 \%$ \\
& 1.62 & 2.09 & & 2.14 & 1.55 & \\
\hline IV & $278.5 \pm$ & $269.3 \pm$ & $254.9 \pm 1.20$ & $253.8 \pm$ & $232.8 \pm$ & $16.40 \%$ \\
\hline
\end{tabular}




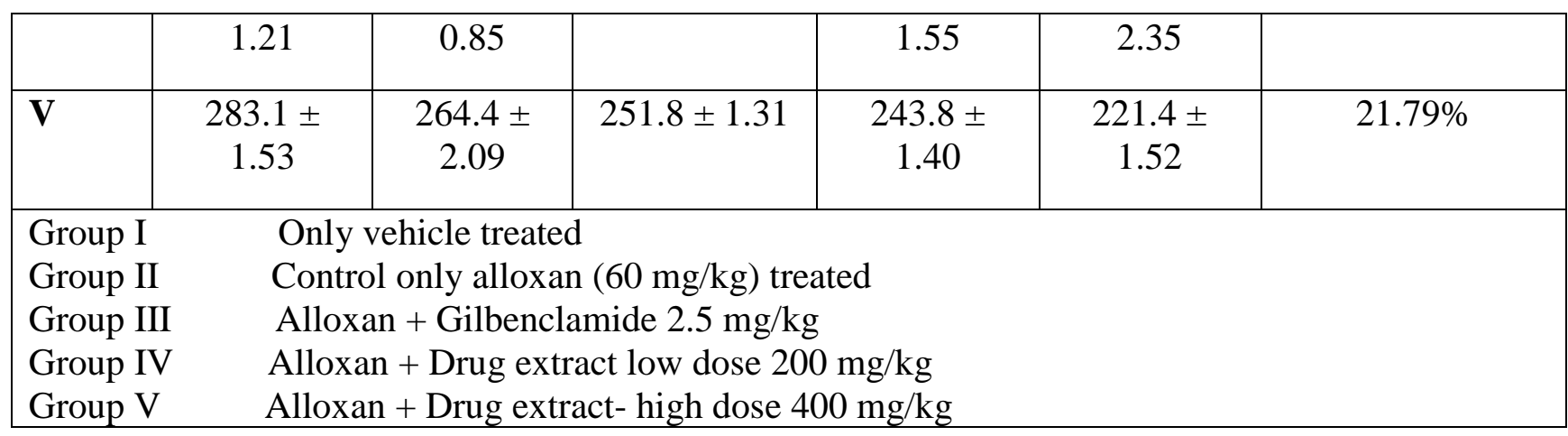

Alloxan at dose of $60 \mathrm{mg} / \mathrm{kg}$ was i.p. administered, after the administration of different treatment. Blood glucose level was estimated at zero, 2, 4, 6 and $8 \mathrm{~h}$ after treatment. Percentage reduction in Blood glucose level in different treated groups after 8 hours was measured and found to be 24.25 ,
16.40 and $21.79 \%$ for glibenclamide, Drug extract at low dose $200 \mathrm{mg} / \mathrm{kg}$ and Drug extract at dose $400 \mathrm{mg} / \mathrm{kg}$ treated group respectively.

Results of alloxan induced diabetic rats (single day study) are given in Table 3 and Figure 2.

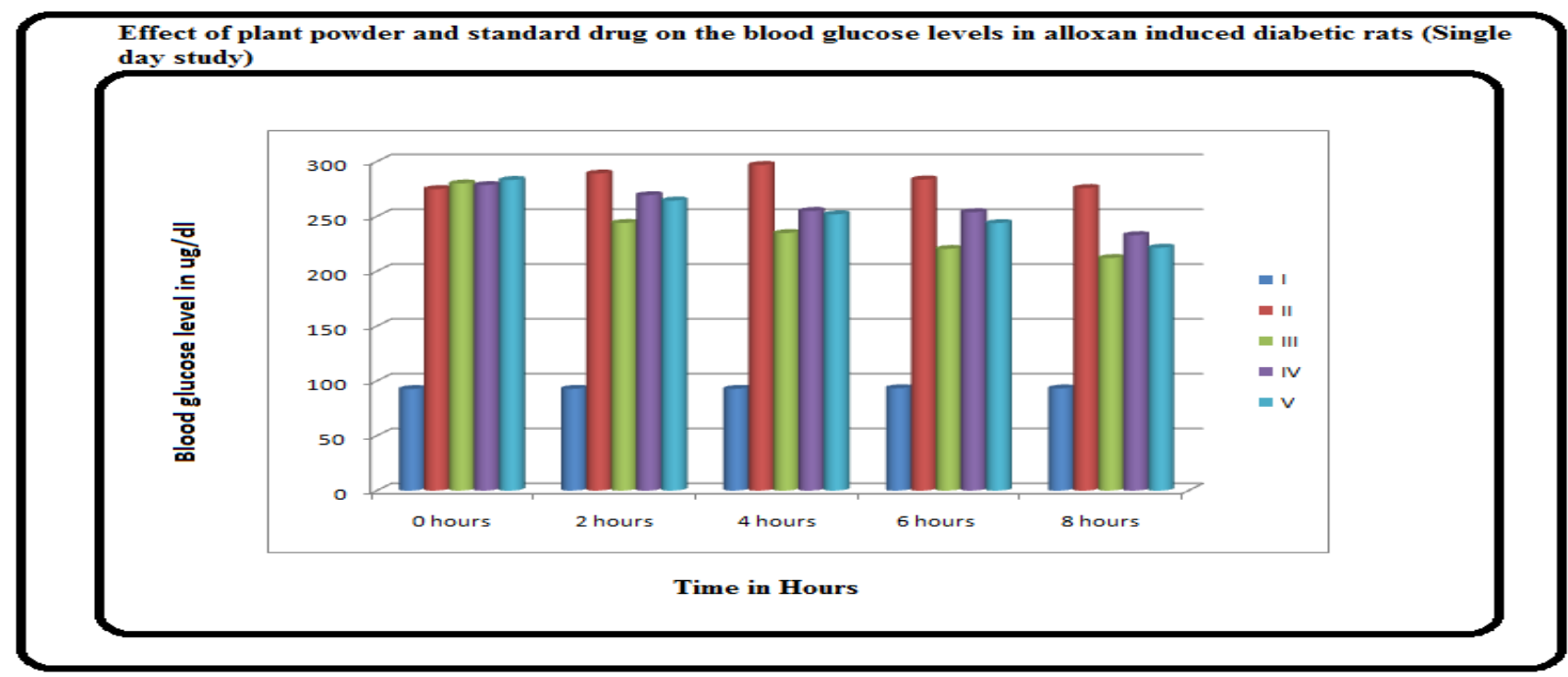

Figure 2: Effect of plant powder and standard drug on the blood glucose levels in alloxan induced diabetic rats (Single day study)

Table 4: Effect of plant powder and standard drug on the blood glucose levels in streptozotocin induced diabetic rats (Single day study)

\begin{tabular}{|l|c|c|c|c|c|c|}
\hline Group & $\mathbf{0 ~ h}$ & $\mathbf{2 ~ h}$ & $\mathbf{4} \mathbf{h}$ & $\mathbf{6 ~ h}$ & $\mathbf{8} \mathbf{~ h}$ & $\begin{array}{c}\text { \% reduction of blood } \\
\text { glucose level after }\end{array}$ \\
\hline I & $92.5 \pm$ & $92.7 \pm$ & $91.8 \pm$ & $93.1 \pm$ & $92.9 \pm$ & - \\
& 1.173 & 1.106 & 1.047 & 0.971 & 0.940 & - \\
\hline II & $289.1 \pm$ & $281.8 \pm$ & $285.6 \pm$ & $287.5 \pm$ & $291.5 \pm$ & \\
& 1.627 & 1.559 & 2.017 & 1.472 & 1.314 & $18.50 \%$ \\
\hline III & $275.1 \pm$ & $267.9 \pm$ & $260.2 \pm$ & $242.5 \pm$ & $224.2 \pm$ & \\
& 1.202 & 1.490 & 1.551 & 1.894 & 2.441 & $13.99 \%$ \\
\hline IV & $278 \pm$ & $273.9 \pm$ & $263.2 \pm$ & $251.6 \pm$ & $239.1 \pm$ & \\
& 1.431 & 1.605 & 1.895 & 1.753 & 2.721 & \\
\hline
\end{tabular}




\begin{tabular}{|l|c|c|c|c|c|c|}
\hline $\mathbf{V}$ & $\begin{array}{c}277.2 \pm \\
1.743\end{array}$ & $\begin{array}{c}276 \pm \\
1.496\end{array}$ & $\begin{array}{c}268 \pm \\
1.352\end{array}$ & $\begin{array}{c}248.8 \pm \\
1.557\end{array}$ & $\begin{array}{c}230.5 \pm \\
1.499\end{array}$ & $16.84 \%$ \\
\hline Group I & \\
Group II & \multicolumn{4}{l|}{ Only vehicle treated } \\
Group III & \multicolumn{3}{l|}{ Streptozotocin + Gilbenclamide $2.5 \mathrm{mg} / \mathrm{kg}$} \\
Group IV & Streptozotocin + Drug extract low dose $200 \mathrm{mg} / \mathrm{kg}$ \\
Group V & Streptozotocin + Drug extract- high dose $400 \mathrm{mg} / \mathrm{kg}$ \\
\hline
\end{tabular}

Effect of plant powder and standard drug on the blood glucose levels in streptozotocin induced diabetic rats (Single day study)

Streptozotocin at dose of $70 \mathrm{mg} / \mathrm{kg}$ was i.p. administered, after the administration of different treatment. Blood glucose level was estimated at zero, 2, 4, 6 and $8 \mathrm{~h}$ after treatment. Percentage reduction in Blood glucose level in different treated groups after 8 $\mathrm{h}$ was measured and found to be 18.50, 13.99 and $16.84 \%$ for glibenclamide, Drug extract at low dose $200 \mathrm{mg} / \mathrm{kg}$ and Drug extract at dose $400 \mathrm{mg} / \mathrm{kg}$ treated group respectively.

Results of alloxan induced diabetic rats (single day study) are given in Table $\mathbf{4}$ and Figure 3.



Figure 3: Effect of plant powder and standard drug on the blood glucose levels in streptozotocin induced diabetic rats (Single day study)

Extractive values were determined by maceration process using non-polar solvent petroleum ether $\left(40-60^{\circ} \mathrm{C}\right)$, benzene and polar solvent ethanol and water. The extractive values of plant powder have been found to be 13.80 to $19.17 \%$ w/w with polar solvents ethanol and water and $12.30 \%$ w/w to $11.26 \%$ w/w with non-polar solvent petroleum ether $\left(40-60^{\circ} \mathrm{C}\right)$ and benzene. This indicates that both polar and non-polar constituents were present in plants powder.

Hydro-alcohol extract showed maximum amount of yield hence for the study hydroalcohol extract was prepared by maceration.

Glucose at dose of $2 \mathrm{~g} / \mathrm{kg}$ was orally administered, after the administration of different treatment. Blood glucose level was estimated at zero, 30, 60, 120 and 240 minutes after treatment. Percentage reduction in Blood glucose level in different treated groups after 240 minutes was measured and found to be $34.27, \quad 15.21, \quad 17.88$ and $14.66 \%$ for glibenclamide, Drug extract at low dose 200 $\mathrm{mg} / \mathrm{kg}$ and Drug extract at dose $400 \mathrm{mg} / \mathrm{kg}$ treated group respectively.

Hypoglycemic effect in glucose treated model. Alloxan at dose of $60 \mathrm{mg} / \mathrm{kg}$ was i.p. administered, after the administration of different treatment. Blood glucose level was estimated at zero, 2, 4, 6 and 8 hours after treatment. Percentage reduction in Blood glucose level in different treated groups after 8 hours was measured and found to be 24.25 , 16.40 and $21.79 \%$ for glibenclamide, Drug 
extract at low dose $200 \mathrm{mg} / \mathrm{kg}$ and Drug extract Streptozotocin at dose of $70 \mathrm{mg} / \mathrm{kg}$ was i.p. administered, after the administration of different treatment. Blood glucose level was estimated at zero, 2, 4, 6 and $8 \mathrm{~h}$ after treatment. Percentage reduction in Blood glucose level in different treated groups after 8 hours was measured and found to be 18.50, 13.99 and $16.84 \%$ for glibenclamide, Drug extract at low dose $200 \mathrm{mg} / \mathrm{kg}$ and Drug extract at dose $400 \mathrm{mg} / \mathrm{kg}$ treated group respectively.

\section{Conclusion}

The present study is a prospective double-blind placebo controlled study conducted to evaluate the potential for greater efficacy with dual placebo and drug powder in patients with diabetic and non-diabetic individuals. The study was conducted in total 200 patients with 100 subjects in each group. Two treatment plans were given randomly to each group. After decoding, these groups were as follows:

\section{a. Group A: Placebo \\ b. Group B: Drug powder}

Duration of treatment was 3 months for each group. All groups showed non-significant difference in baseline demographic profile (age, sex, BMI etc.; $p>0.05$ ). So, all the groups were matched for all variables. Various parameters of $\mathrm{W} / \mathrm{H}$ ratio, $\mathrm{BMI}$, Blood serum comparison were assessed weekly while electrophysiological parameters were assessed at the beginning and at the end of study.

The findings are summarized as follows:

Patients on placebo showed less significant in diabetic patients scores ( $>0.05)$ with nonsignificant improvement in electrophysiological parameters $(\mathrm{p}>0.05)$. Patients on drug powder showed significant improvement $(\mathrm{p}<0.05)$ in electrophysiological parameters with slight improvement in pain scores.

Diabetic neuropathy does not lead to mortality but affect the quality of life significantly. Various drugs are effective in the management of diabetes but none is completely satisfactory except improvement with drug powder. at dose $400 \mathrm{mg} / \mathrm{kg}$ treated group respectively. Significant improvement was noted in diabetic parameters in patients who received drug powder compared to patients who received placebo. Patients in drug powder group had improvement in management of diabetes as well as subjective relief in symptoms with diabetes while placebo group had no significant change in pain score at the end of 12 weeks. Further larger and longer duration trials are required to establish the efficacy and safety of drug powder in treatment of diabetic as well as its comparison with other groups of drugs before it can he proved to be better than other drugs in controlling the painful diabetic neuropathy symptoms.

To conclude, present study shows a better result in management of diabetic when drug powder used in therapy is well tolerated by patients.

\section{References}

1. Jahangir MA, Imam SS, Kazmi I, et al. Type 2 Diabetes Current and Future Medications: A Short Review. Int J Pharm Pharmacol 2017; 1: 101.

2. Danaei G, Finucane MM, Lu Y, et al. National, Regional and global trends in fasting plasma glucose and diabetes prevalence since 1980: Systematic analysis of health examination surveys and epidemiological studies with 370 countryyears and 2.7 million participants. Lancet 2011; 378: 31-40.

3. Global health risks. Mortality and burden of disease attributable to selected major risks, Geneva, World Health Organization, 2009.

4. Mathers CD, Loncar D. Projections of global mortality and burden of disease from 2002 to 2030. PLoS Med 2006; 3: e442.

5. Global status report on noncommunicable diseases 2010. Geneva, World Health Organization, 2011.

6. Ganong FM. Review of Medical Physiology, $11^{\text {th }}$ Ed., Prentice Hall International Inc., 1983: 279.

7. Suzuki O, Miyachi N, Kuto $K$, et al. International Patent WO 95/26347, $5^{\text {th }}$ Oct 1955/Preparation of Pyridine Substituted Thiazolidine and Oxazolidine Hypoglycemic Agents. Chem Abst 1996; 124: 146181. 
8. Ueno H, Suchira I, Nakamura F. European Patent, 604 92/349, 172, 28 $8^{\text {th }}$ Dec 1992/Chem Abst 1995; 122: 187584.

9. Murray RK, Granner DK., Mayer PA, et al. Harper's Biochemistry, 24 ${ }^{\text {th }}$ Ed., Prentice Hall International Inc., USA 1996: 586.

10. Foye WO, Lemke TL, Williams DA. Principles of Medicinal Chemistry, $4^{\text {th }}$ Ed., BS Waverly Pvt Ltd., New Delhi 1995: 581.

11. Tripathi KD. Essential of Medical Pharmacology, $4^{\text {th }}$ Ed., Jaypee Brothers Medical Publishers Pvt Ltd., New Delhi 1999: 276.

12. Khandelwal RK. Practical Pharmacognosy: Techniques and Experiments. $9^{\text {th }}$ Ed., Nirali Prakashan 2005; 149-161.

13. OECD Guideline for testing of chemicals. Acute oral toxicity-Acute Toxic Class Method 423: 2001.

14. World Health Organization and International Diabetes Federation. Definition, diagnosis and classification of diabetes mellitus and its complications. Geneva, Switzerland: 1999.

15. Szkudelski T. The mechanism of alloxan and streptozotocin action in $\beta$ - cells of the pancreas. Physiol Res 2001; 50: 536-546.

16. Pillai NK. History of Siddha Medicine, Department of India Medicine and Homeopathy. Chennai 1998: 33-35.

17. Yesilada E, Sezik E, Honda G, et al. Traditional medicine in Turkey IX: Folk medicine in north-west Anatolia. J. Ethanopharmacol 1999; 64: 195-210.

18. Leporatti ML, Corradi L. Ethnopharmacobotanical remarks on the province of Chieti town (Abbruzzo, central Itlay). J Ethnopharmacol 2001,74: 17-40.

19. Ghorbani A. Best herbs for managing diabetes: A review of clinical studies. Brazilian J Pharma Sci 2013; 49: 413-422.

20. Bordoloi R, Dutta KN. A Review on Herbs Used in the Treatment of Diabetes mellitus. J Pharma Chem Bio Sci 2014; 2: 86-92.

21. Manisha M, Dixit P, Londhe J, et al. Indian Herbs and Herbal Drugs used for the treatment of Diabetes. J Clin Biochem Nutr 2007; 40: 163-173.

22. Ríos JL, Francini F, Schinella GR. Natural Products for the Treatment of Type 2 Diabetes Mellitus. Planta Med 2015; 81: 975-994.

23. Ahmad M, Qureshi R, Arshad M, et al. Traditional Herbal Remedies used for the Treatment of Diabetes from District Attock (Pakistan). Pak J Bot 2009; 41: 2777-2782.

24. Rao MU, Sreenivasulu M, Chengaiah B, et al. Herbal Medicines for Diabetes Mellitus: A Review. Int J PharmTech Res 2010; 2: 1883-1892.

25. Dwivedi C, Daspaul S. Antidiabetic Herbal Drugs and Polyherbal Formulation Used for Diabetes: A Review. J Phytopharmacol 2013; 2: 44-51.

26. Jarald E, Joshi SB, Jain DC. Diabetes and Herbal Medicines. Iranian J Pharmacol Therap 2008; 7: 97-106.

27. Bailey C, Day C. Traditional Plant Medicines as Treatments for Diabetes. Diabetes Care 1989; 12: 553-564.

28. Matheka DM, Alkizim FO. Complementary and alternative medicine for type 2 Diabetes mellitus: Role of medicinal herbs. J Diabetes Endocrinol 2012; 3: 44-56.

29. Eddouks M, Maghrani M, Lemhadri A, et al. Ethnopharmacological survey of medicinal plants used for the treatment of diabetes mellitus, hypertension and cardiac diseases in the south-east region of Morocco (Tafilalet). J. Ethnopharmacol 2002; 82: 97-103.

30. Narayan DS, Patra VJ, Dinda SC. Diabetes and Indian Traditional Medicines: An Overview. Int J Pharm Pharm Sci 2012; 4: 45-53.

\section{Conflict of Interest}

None declared.

\section{Funding}

None declared. 
This manuscript was peer-reviewed

Mode of Review: Single-blinded

Editor: Dr. Bijaya Kumar Mohanti

International Journal of Pharmaceutics and Pharmacology is an open access, peer reviewed journal published by Edwiser International.

Submit your valuable manuscript at-

editor.ijpp@edwiserinternational.com

submit.manuscript@edwiserinternational.com

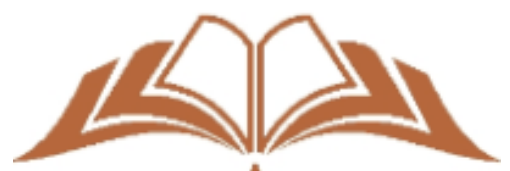

$\mathrm{E} D \mathrm{~W}(\hat{\mathrm{\theta}} \mathrm{SER}$

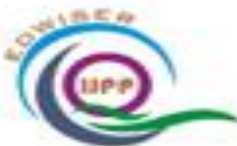

International Journal of Pharmaceutics \& Pharmacology

International Journal of General Medicine \& Surgery
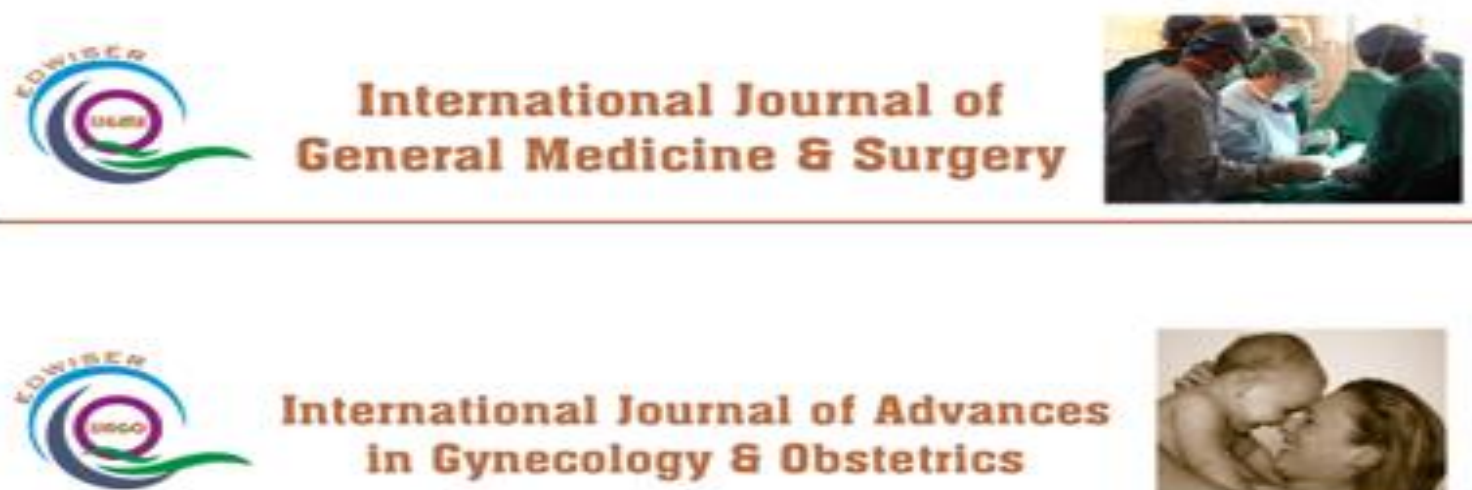

International Journal of Advances in Gynecology \& Obstetrics
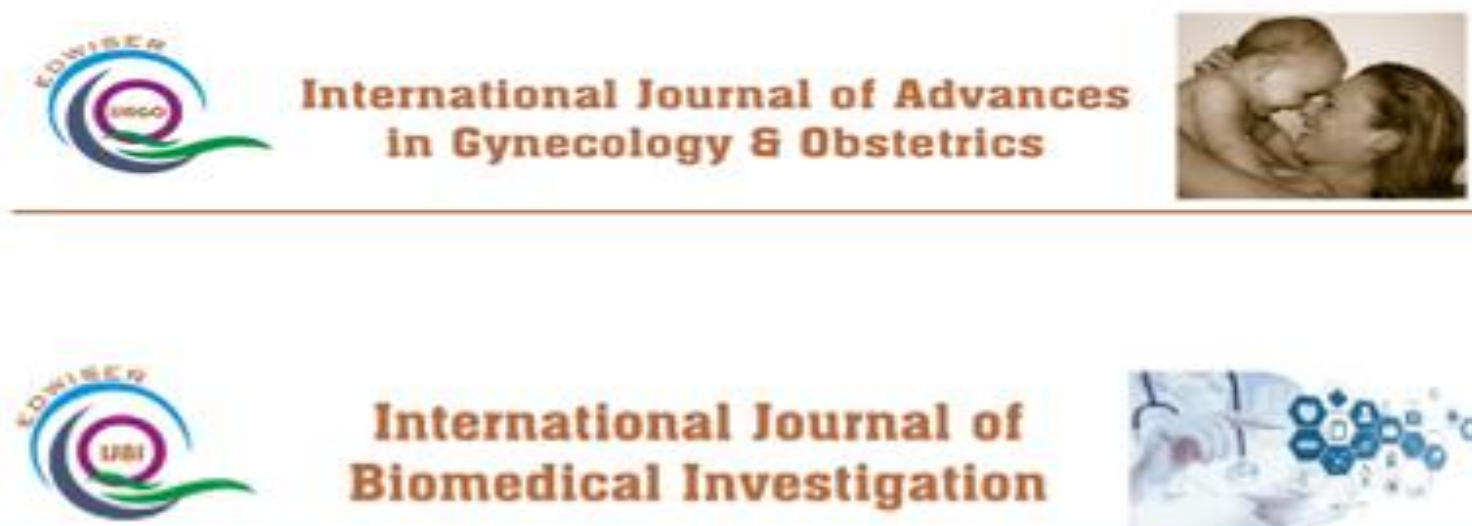

\section{International Journal of Biomedical Investigation}
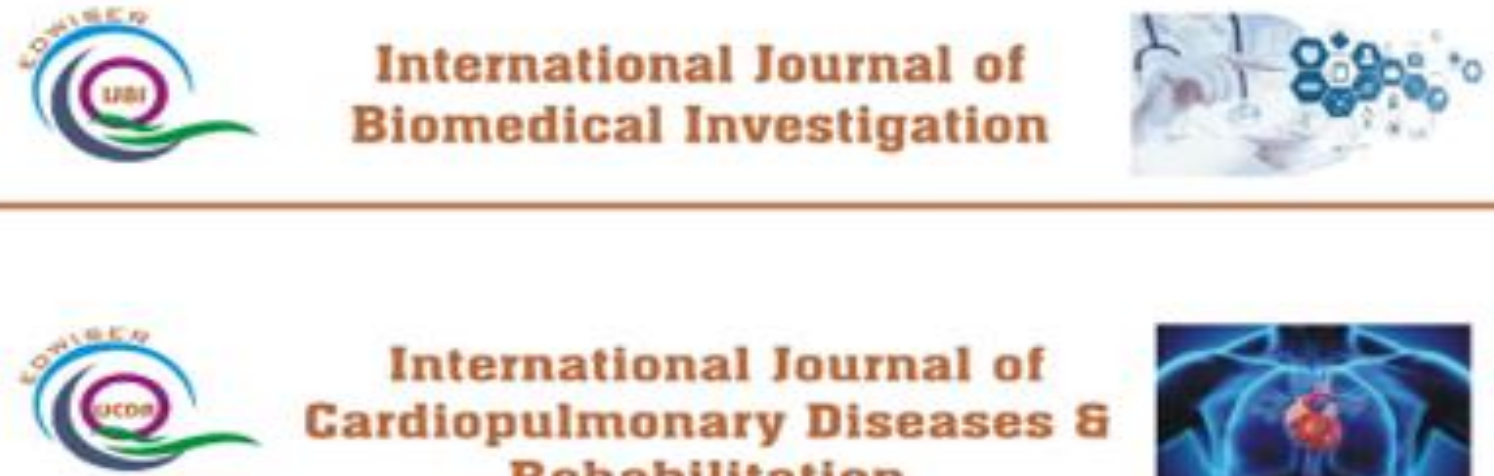

\section{International Journal of Cardiopulmonary Diseases \& Rehabilitation}

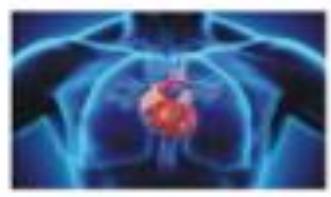

